\title{
Workshop Pemanfaatan Rumput Laut Untuk Pembuatan Ice Gel Bagi Masyarakat Pulau Tidung, Kab. Kepulauan Seribu, Prov. DKI Jakarta
}

\author{
Johansyah Lubis ${ }^{1}$, Mustofa Masyhur ${ }^{2}$ dan Nurfitranto ${ }^{3}$ \\ ${ }^{1,2}$ Pendidikan Jasmani, Universitas Negeri Jakarta; \\ ${ }^{3}$ Pendidikan Kepelatihan Olahraga, Universitas Negeri Jakarta; \\ johansyah.sport@unj.ac.id; masyhur73@gmail.com; nfitranto@gmail.com
}

\begin{abstract}
,
This community service program was aimed to help the community bycommunicating the utilization of algae to produce ice gel of which need recently grows greatly as it is commonly used in the recovery process of an ill child, recovery process in general, or for an economical purpose. To produce ice gel, any material can be used. Algae is one of them. The PulauTidung community as one of the algae farmers is seen not to have utilized the algae optimally. They prefer to sell their harvest to the middlemen. The objective of this program with workshop as its method was to increase the awareness of PulauTidung community of basic knowledge about algae and help them acquire the competence in utilizing algae to produce ice gel which then could be used in recovery process. During workshop, all participants seem to be enthusiastic in following all activities and they received support from both local and regency governments.
\end{abstract}

Keywords: Workshop, algae, ice gel, PulauTidung.

\begin{abstract}
Abstrak ,
Pengabdian Kepada Masyarakat ini bertujuan membantu dan mensosialisasikan pemanfaatan rumput laut untuk dibuat ice gel, dimana kebutuhan akan ice gel, saat ini semakin besar, karena digunakan untuk proses recovery anak yang sedang sakit, proses recovery, atau untuk kepentingan ekonomi, pembuatan ice gel dapat dilakukan dengan berbagai cara salah satu sumbernya adalah dengan rumput laut (algae), dimasyarakat Pulau Tidung yang merupakan salah satu daerah penghasil rumput laut, masih belum optimal pemanfaatannya, petani lebih senang menjual hasil panennya kepada tengkulak, PkM ini dengan metode workshop, dimana Target luaran yang diharapkan setelah pelaksanaan workshop ini adalah meningkatkan kemampuan masyarakat pulau Tidung tentang pengetahuan dasar algae serta kemampuan pemanfaatan rumput laut menjadi ice gel yang akan dimanfaatkan untuk proses recovery. Pada pelaksanaannya semua peserta antusias mengikuti dengan baik dan mendapat dukungan dari pemerintah setempat bahkan dari Pemerintah Kabupaten.
\end{abstract}

Kata Kunci : Workshop, rumput laut, ice gel, Pulau Tidung.

\section{PENDAHULUAN}

Ice gel merupakan alat yang akan digunakan sebagai proses recovery dalam olahraga, dimana pada tahun 2017 telah dilakukan penelitian dengan pengembangan model vest cool berbasis serat protein untuk recovery atlet, didalam perjalanaan penelitian, peneliti mengalami kesulitan dalam menemukan ice gel yang digunakan dalam vest cool yang berbasis serat protein (Lubis Johansyah and S., Dewi. 2017)

Kebutuhan akan ice gel yang ada saat ini masih cukup mahal dan berasal dari produk luar negeri, sehingga sangat sulit diperoleh, Munculnya ide mengembangkan ice gel mengalir begitu saja setelah hasil Focus Group 
DOI: https://doi.org/10.21009/sarwahita.151.06

P-ISSN: 0216-7484

E-ISSN: 2597-8926

Discussion yang telah dilakukan, dengan alternatif menggunakan alga, tepung tapioka dan lain sebagainya. Alga dipilih dalam PKM tahun ini dengan beberapa pertimbangan karena alga atau rumput laut sangat jarang dimanfaatkan oleh masyarakat atau petani, mengingat pemanfaatkan rumput laut yang digunakan masih berkisar makanan dan kebutuhannnya lainnya yang masih kurang.

Petani rumput laut yang dekat dari peneliti adalah di pulau Tidung, Pada tahun 1800an pulau tidung sudah dihuni oleh penduduk walaupun jumlahnya pada waktu itu masih sedikit. Pulau tidung terdiri dari 2 pulau kecil yaitu: Pulau Tidung Besar dan Pulau Tidung Kecil, konon menurut sumber cerita bahwa Pulau yang pertama dihuni penduduk adalah Pulau Tidung Kecil, dengan bertambahnya tahun demi tahun penduduk semakin bertambah dan barulah hijrah ke Pulau Tidung Besar.

Penduduk Pulau Tidung Berasal dari bermacam-macam suku diantaranya suku Bugis, Mandar, Kalimantan Timur, Kalimantan Barat, Sumatera, Sumbawa dan Banten bahkan ada dari Batavia. kala itu agama yang dianut oleh para penduduk setempat dan pendatang adalah agama Islam, dan pada saat gunung Krakatau meletus sedang di-Pulau Tidung sudah dihuni oleh banyak penduduk terutama dari keturunan para pendatang.

Istilah "rumput laut" dimasyarakat adalah rancu secara botani karena dipakai untuk dua kelompok "tumbuhan" yang

berbeda. Dalam bahasa Indonesia, istilah rumput laut dipakai untuk menyebut baik gulma laut dan lamun.Yang dimaksud sebagai gulma laut adalah anggota dari kelompok vegetasi yang dikenal sebagai alga ("ganggang"). Sumber daya ini biasanya dapat ditemui di perairan yang berasosiasi dengan keberadaan ekosistem terumbu karang. Gulma laut alam biasanya dapat hidup di atas substrat pasir dan karang mati. Di beberapa daerah pantai di bagian selatan Jawa dan pantai barat Sumatera, gulma laut banyak ditemui hidup di atas karang-karang terjal yang melindungi pantai dari deburan ombak. Di pantai selatan Jawa Barat dan Banten misalnya, gulma laut dapat ditemui di sekitar pantai Santolo dan Sayang Heulang di Kabupaten Garut atau di daerah Ujung KulonKabupaten Pandeglang. Sementara di daerah pantai barat Sumatera, gulma laut dapat ditemui di pesisir barat Provinsi Lampung sampai pesisir Sumatera Utara dan Aceh. (Afrianto dan Liviawati, 1993)

Selain hidup bebas di alam, beberapa jenis gulma laut juga banyak dibudidayakan oleh sebagian masyarakat pesisir Indonesia. Contoh jenis gulma laut yang banyak dibudidayakan di antaranya adalah Euchema cottonii dan Gracilaria spp(Atmadja, W. S., A. Kadi., Sulistijo, dan Rachmaniar. 1996). Beberapa daerah dan pulau di Indonesia yang masyarakat pesisirnya banyak melakukan usaha budidaya gulma laut ini di antaranya berada di wilayah pesisir Kabupaten Administrasi Kepulauan Seribu, Provinsi 
DOI: https://doi.org/10.21009/sarwahita.151.06

P-ISSN: 0216-7484

E-ISSN: 2597-8926

Kepulauan Riau, Pulau Lombok, Sulawesi, Maluku dan Papua.

Perkembangbiakan terjadi baik dengan cara seksual maupun aseksual. Pembentukan spora dalam organ-organ yang dinamakan sporangium umum terjadi pada warga divisi ini. Perkembangbiakan seksual terjadi melalui peleburan gamet-gamet yang terbentuk dalam organ-organ yang disebut gametangium. Istilah-istilah yang bertalian dengan cara perkembangbiakan seksual pada tumbuhan talus seperti misalnya :isogami, anisogami, gametangiogami, dan oogami, mencerminkan adanya perbedaan sifat gamet yang beraneka ragam.

Mengenai cara hidupnya dapat ditemukan 3 cara yang berbeda, yaitu hidup secara autotrof, dapat mengadakan asimilasi dengan fotosintesis, ada yang hidup secara heterotrof, dan dengan ada yang suatu simbiosis (Fatimah, 2012).

Berdasar ciri-ciri utama yang menyangkut cara hidupnya, divisi Thallophytha dibedakan dalam 3 anak divisi, yaitu :

1. Ganggang (Algae)

2. Jamur (Fungi)

3. Lumut Kerak (Lichenes)

Tumbuhan Ganggang atau lebih dikenal dengan nama alga ini merupakan tumbuhan talus yang hidup di air, baik air tawar maupun laut, setidak-tidaknya selalu menempati habitat yang lembab/basah(Atmadja dan Sulistija. 1988). Yang hidup di air ada yang bergerak aktif ada yang tidak. Jenis-jenis

yang hidup bebas di air, terutama yang tubuhnya bersel tunggal dan dapat bergerak aktif merupakan penyusun plankton, tepatnya fitoplankton. Yang melekat pada sesuatu yang ada di dalam air, misalnya batu atau kayu, disebut bentos. Jenis-jenis yang dapat bergerak aktif mempunyai alat untuk bergerak yang berupa bulu cambuk atau flagel. Flagel pada ganggang berjumlah satu atau lebih. Jika jumlahnya lebih dari satu, flagel itu dikatakan isokon bila sama panjangnya, heterokon bila panjangnya tidak sama.

Walaupun tumbuh ganggang menunjukkan keanekaragaman yang sangat besar, tetapi semua selnya selalu jelas mempunyai inti dan plastida, dan dalam plastidanya terdapat zat-zat warna derivat klorofil, yaitu klorofil-a atau klorofil-b atau kedua-duanya. Selain derivat-derivat klorofil terdapat pula zatzat warna lain, dan zat warna lain inilah yang justru kadang-kadang lebih menonjol dan menyebabkan kelompokkelompok ganggang tertentu diberi nama menurut warna tadi. Zat-zat (pigmen) tersebut berupa :

- Fikosianin : warna biru

- Klorofil : warna hijau

- Fikosantin : warna pirang/coklat

- Fikoeritrin : warna merah

- Karoten : warna keemasan

- Xantofil : warna kuning

Terutama karna adanya derivatderivat klorofil itu, tumbuhan ganggang dapat berasimilasi dengan fotosintesis, jadi ganggang itu bersifat autrotrof. 
DOI: https://doi.org/10.21009/sarwahita.151.06

P-ISSN: 0216-7484

E-ISSN: 2597-8926

Ganggang yang heterotrof, yang hidup sebagai parasit dan bersifat patogen jarang terdapat.

Ganggang merupakan sumberdaya nabati berbagai bahan kebutuhan hidup manusia. Ada yang langsung dimakan sebagai sayuran, misalnya beberapa jenis ganggang hijau, ada yang menghasilkan agar-agar (berbagai jenis ganggang merah) (Rasyid, 2003), ada yang menghasilkan bahan obat (beberapa jenis ganggang pirang dan ganggang merah), ada pula yang menghasilkan berbagai zat

yang berguna, seperti: soda, manit, yodium, dan lain-lain.

Ganggang dapat dibedakan dalam 6 filum, yaitu :

1. Chlorophyta (Alga Hijau)

2. Phaeophyta (Alga Coklat/Pirang)

3. Rhodophyta (Alga Merah)

4. Chrysophyta (Alga Keemasan)

5. Phyrophyta (Alga Api)

6. Euglenophyta (Alga Berflagel)

Berikut merupakan ciri umum dari semua filum ganggang diatas, yaitu sbb :

\begin{tabular}{|c|c|c|c|c|c|c|}
\hline Ciri-ciri & Chlorophyta & Phaeophyta & Rhodophyta & Chrysophyta & Phyrophyta & Euglenophyta \\
\hline Pigmen & $\begin{array}{l}\text { Klorofil a dan } \\
\text { b, karoten, } \\
\text { dan xantofil }\end{array}$ & $\begin{array}{l}\text { Klorofil a dan } \\
\text { b, karoten, dan } \\
\text { fukosantin } \\
\text { xantofil }\end{array}$ & $\begin{array}{l}\text { Klorofil a } \\
\text { dan b, } \\
\text { karotenoid, } \\
\text { fikosianin, } \\
\text { fikoeritrin }\end{array}$ & $\begin{array}{l}\text { Klorofil a dan } \\
\text { b, karoten, } \\
\text { dan xantofil }\end{array}$ & $\begin{array}{l}\text { Klorofil a } \\
\text { dan c, } \\
\text { karoten, dan } \\
\text { xantofil }\end{array}$ & $\begin{array}{l}\text { Klorofil a dan } \\
\text { b, karoten, } \\
\text { dan xantofil }\end{array}$ \\
\hline Habitat & $\begin{array}{l}90 \% \text { hidup di } \\
\text { air tawar dan } \\
10 \% \text { hidup di } \\
\text { air laut }\end{array}$ & $\begin{array}{l}\text { Pantai, air } \\
\text { laut, air tawar }\end{array}$ & $\begin{array}{l}\text { Air tawar } \\
\text { dan air laut }\end{array}$ & $\begin{array}{l}\text { Air tawar dan } \\
\text { air laut }\end{array}$ & $\begin{array}{l}\text { Kebanyakan } \\
\text { dilaut, } \\
\text { sebagian } \\
\text { kecil di air } \\
\text { tawar }\end{array}$ & $\begin{array}{l}\text { Hidup di air } \\
\text { tawar, dalam } \\
\text { kolam/tempat } \\
\text { yang } \\
\text { berlumpur }\end{array}$ \\
\hline $\begin{array}{l}\text { Cadangan } \\
\text { makanan }\end{array}$ & Pati & $\begin{array}{l}\text { Laminosin } \\
\text { manitol }\end{array}$ & $\begin{array}{l}\text { Bahan agar- } \\
\text { agar }\end{array}$ & $\begin{array}{l}\text { Leukosin dan } \\
\text { minyak }\end{array}$ & Pati & Pati \\
\hline Bentuk talus & $\begin{array}{l}\text { Benang, } \\
\text { lembaran, bola }\end{array}$ & $\begin{array}{l}\text { Benang / } \\
\text { seperti } \\
\text { tumbuhan } \\
\text { tingkat tinggi }\end{array}$ & $\begin{array}{l}\text { Benang / } \\
\text { seperti } \\
\text { tumbuhan } \\
\text { tingkat } \\
\text { tinggi }\end{array}$ & $\begin{array}{l}\text { Benang, } \\
\text { lembaran, bola }\end{array}$ & $\begin{array}{l}\text { Ada yang } \\
\text { bulat, dan } \\
\text { ada yang } \\
\text { berbentuk } \\
\text { seperti garpu }\end{array}$ & $\begin{array}{l}\text { Lonjong dan } \\
\text { ada flagel/bulu } \\
\text { cambuk }\end{array}$ \\
\hline Reproduksi & $\begin{array}{l}\text { Aseksual } \\
\text { (zoospora) dan } \\
\text { seksual } \\
\text { (konjugasi) }\end{array}$ & $\begin{array}{l}\text { Aseksual } \\
\text { (zoospora } \\
\text { berflagel dua } \\
\text { dan } \\
\text { fragmentasi) } \\
\text { dan seksual } \\
\text { (isogami/ooga } \\
\text { mi) }\end{array}$ & $\begin{array}{l}\text { Aseksual } \\
\text { (spora } \\
\text { haploid) dan } \\
\text { seksual } \\
\text { (persatuan } \\
\text { sel } \\
\text { spermatium } \\
\text { dan } \\
\text { karpogoniu } \\
\text { m) }\end{array}$ & $\begin{array}{l}\text { Aseksual } \\
\text { (zoospora } \\
\text { berflagel } \\
\text { banyak) dan } \\
\text { seksual } \\
\text { (konjugasi) }\end{array}$ & $\begin{array}{l}\text { Membelah } \\
\text { diri }\end{array}$ & $\begin{array}{l}\text { Pembelahan } \\
\text { biner }\end{array}$ \\
\hline Dinding sel & Selulosa & $\begin{array}{l}\text { Selulosa, asam } \\
\text { alginate }\end{array}$ & $\begin{array}{l}\text { Manan dan } \\
\text { xilan }\end{array}$ & Kersik/silica & Selulosa & Pati \\
\hline
\end{tabular}


DOI: https://doi.org/10.21009/sarwahita.151.06

P-ISSN: 0216-7484

E-ISSN: 2597-8926

\begin{tabular}{|c|c|c|c|c|c|c|}
\hline Peranan & $\begin{array}{l}\text { Fitoplankton } \\
\text { dalam } \\
\text { ekosistem air, } \\
\text { bahan } \\
\text { makanan }\end{array}$ & $\begin{array}{l}\text { Fitoplankton } \\
\text { dalam } \\
\text { ekosistem air, } \\
\text { asam alginat } \\
\text { untuk industri } \\
\text { makanan, } \\
\text { farmasi, dan } \\
\text { pupuk }\end{array}$ & $\begin{array}{l}\text { Bahan agar- } \\
\text { agar dan sup }\end{array}$ & $\begin{array}{l}\text { Plankton, } \\
\text { produsen di } \\
\text { perairan laut }\end{array}$ & $\begin{array}{l}\text { Bahan alat } \\
\text { penyadap } \\
\text { suara, } \\
\text { pembuat cat, } \\
\text { pernis, dan } \\
\text { piringan } \\
\text { hitam }\end{array}$ & - \\
\hline Contoh & $\begin{array}{l}\text { Chlorella, } \\
\text { Ulva, } \\
\text { Spirogyra }\end{array}$ & $\begin{array}{l}\text { Turbinaria, } \\
\text { Fucus, } \\
\text { Sargassum }\end{array}$ & $\begin{array}{l}\text { Gracilaria, } \\
\text { Gelidium, } \\
\text { Eucheuma }\end{array}$ & $\begin{array}{l}\text { Navicula, } \\
\text { Pinnularia, } \\
\text { Synura }\end{array}$ & $\begin{array}{l}\text { Perodinium, } \\
\text { Ceratium }\end{array}$ & $\begin{array}{l}\text { Euglena } \\
\text { viridis, } \\
\text { Gracilis }\end{array}$ \\
\hline
\end{tabular}

Manfaat yang dapat peroleh dari alga, tidak hanya untuk dikonsumsi saja tapi bisa digunakan di bidang kesehatan (Anggadiredja, 2007). Secara umum alga mempunyai manfaat sebagai berikut: a. Sumber Utama Energi Makanan

Alga dipercaya merupakan salah satu penghasil utama bahan organik di dalam ekosistem perairan. Keberadaannya merukan bagian yang paling utama dari sistem rantai makanan. Aktifitas fotosintesi yang mampu dilakukannya di dalam air, dapat dijadikan sumber oksigen yang sangat bemanfaat bagi lingkungan sekitar tempat ia tumbuh. Sebagai tumbuhan yang memilki klorofil, alga mampu meyerap energi matahari, dan kemudian tubuhnya dijadikan sumbert makan oleh para mahkluk di perairan. Alga merupakan jenis makanan yang dapat memastikan keberlangsungan kehidupan hewa-hewan yang ada di laut(Dahuri, R. 2002).

\section{b. Bahan Makan Manusia}

Banyak sekali jenis alga di dunia ini yang dapat dimanfaatkan sebagai bahan makan untuk manusia. Contohnya di jepang. Ada jenis makanan di Jepang yang disebut Kombu, terbuat dari laminaria (salah satu dari jenis laga cokelat) yang mengandung fe dan protein yang tinggi serta memberikan manfaat vitamin A dan C. Sejak dahulu kala, manusia memang telah menemukan beragam jenis alga yang dapat dikomsumsi, dan menjadi bahan makanan alternatif pengganti beras maupun jagung. c. Makanan Ternak

Di negara-negara maritim, alga juga dimanfaatkan untuk keperluan pakan ternak. Makanan-makanan ternak yang berasal dari bahan utamanya yaitu alga, dapat dikomsumsi secara langsung maupun diolah menjadi bentuk makanan ternak yang lebih efisien.(Anggadiredja, Zatnika, Purwoto, dan Istini. 2006)

\section{d. Bahan Pembuatan Pupuk}

Hal ini dimungkinkan karena alga memilki kandungan fosfor, kalium, dan beberapa unsur runut. Pembuatannya sendiri dengan mencampur makroalgae dengan bahan-bahan oraganik lainnya.

\section{e. Bahan Obat Dan Anti Biotik}

Pada beberapa jenis alga, juga ditemukan manfaat yang sangat berarti bagi proses pembuatan obat-obatan maupun sebagai antibiotic (Angka, S.L. dan Maggy T. Suhartono. 2000). Alga 
DOI: https://doi.org/10.21009/sarwahita.151.06

P-ISSN: 0216-7484

E-ISSN: 2597-8926

dengan manfaat antibiotik ini diteliti efektif dalam pencegahan bakterti Escherichia colli. Sedangkan pada jenis alga lainnya ditemukan Sfucoidin dan sodium laminarin sulfat yang digunakan sebagai antikoagulan darah. Bahkan pada beberapa jenis alga berfungsi sebagai pengobatan penyakit ginjal, kandung kemih dan paru-paru.

Disamping yang tersebut di atas, alga juga dimanfaatkan sebagai bahan kajian penelitian biologi, membantu penanggulangan limbah serta reklamasi tanah atau diartikan sebagai usaha memperluas tanah (pertanian) dengan memanfaatkan daerah yang semula tidak berguna (misal dengan cara menguruk daerah rawa-rawa).

\section{Pada Tahun 1967 Kecamatan}

Pulau Seribu menjadi kecamatan Kepulauan Seribu dan pada tahun 2002 Kecamatan Kepulauan Seribu menjadi Kabupaten Administrasi Kepulauan Seribu yang memiliki 2 wilayah Kecamatan, Yaitu Kecamatan Kepulauan Seribu Selatan dan Kecamatan Kepulauan Seribu Utara. juga memiliki 6 Kelurahan yaitu Kelurahan Pulau Tidung, Kelurahan Pulau Pari, Kelurahan Pulau Untung Jawa, Kelurahan Pulau Panggang, Kelurahan Pulau Harapan, dan Kelurahan Pulau Kelapa. Luas wilayah Pulau Tidung Besar +54Ha dan Pulau Tidung Kecil +18Ha, Pulau Tidung Besar terdiri dari 4RW dan 29RT terdiri dari $1142 \mathrm{kk}$ dan 4354 jiwa.

Pada tahun 2009 Pulau Tidung mulai dikunjungi para wisatawan yang

berasal dari Jakarta, Bogor, Bandung, tanggerang dan sekitarnya. Masyarakat Pulau Tidung menyambut baik hal ini karena dengan kedatangan para wisatawan itu akan dapat menambah penghasilan masyarakat setempat. hal ini berikut dukungan pemerintah setempat yang dibuktikan dengan terwujudnya jembatan penyeberangan dari Pulau Tidung Besar ke Pulau Tidung kecil dan Jembatan itu dikenal dikalangan wisata sebagai "Jembatan Cinta".

Sejarah pulau Tidung berawal dari sebuah kerajaan di daerah Malinau, Kalimantan Timur. Suku Tidung di Malinau sudah ada sejak tahun tahun 1076 - 1156. Pada tahun itu, kerajaan tersebut dikenal sebagai kerajaan Tidung kuno. Pada tahun 1557 inilah pertama kali pemerintah kolonial Belanda datang ke Malinau. Pada saat itu pemerintah kolonial Belanda mendapat perlawanan berat terutama dari kerajaan Suku Tidung. Penjajah Belanda perlahan-lahan berhasil menguasai daerah sekitar Malinau dan mengepung kerajaan Tidung. Karena semakin terdesak, raja Tidung yang memiliki nama Raja Pandhita akhirnya ditangkap oleh pemerintah kolonial Belanda. Dia diasingkan ke pulau terpencil di daerah utara kota Jepara.

Dari pulau ini, Raja Pandhita yang dikenal dengan sebutan raja Tidung melarikan diri ke sebuah pulau kecil di kepulauan Seribu. Saat itu, pulau kecil ini belum bernama. Masyarakat asli pulau kecil ini memanggil Raja Tidung dengan panggilan "Kaca". Hal yang sangat 
DOI: https://doi.org/10.21009/sarwahita.151.06

P-ISSN: 0216-7484

E-ISSN: 2597-8926

menarik, "Kaca" sangat dihormati oleh warga pulau kecil ini karena suka menolong dan berbagi ilmunya kepada masyarakat. Warga pulau ini tidak mengetahui jika "Kaca" adalah seorang raja terkenal di suku Tidung. Hingga beliau meninggal dan dimakamkan di pulau Tidung ini. Beberapa saat kemudian keluarga kerajaan Tidung datang mencari raja Pandhita. Dan saat itulah diketahui oleh warga Tidung bahwa "Kaca" adalah seorang raja terkenal dari Malinau. Mengingat ingin menghormati dan mengucapkan terima kasih atas jasa beliau, maka pulau kecil ini dinamakan sebagai pulau Tidung. Pulau yang sangat menghormati seorang raja dari suku Tidung, Malinau, Kalimantan Timur. Sampai saat ini, makam raja Tidung masih terjaga kebersihannya di tengah pulau Tidung.

Masyarakat sangat bangga karena pulaunya menjadi bagian sejarah kerajaan besar yaitu kerajaan Tidung. Jika ingin melihat langsung makam dari seorang raja sebuah kerajaan yang mengharumkan bangsa Indonesia karena menentang dan melakukan perlawanan kepada kolonial Belanda, dapat menikmati paket wisata pulau Tidung.

\section{Bagi warga Pulau Tidung}

Kepulauan Seribu Selatan mungkin tidak asing lagi mendengar nama "Panglima Hitam" yang berasal Cirebon Banten Jawa Barat dan dikenal sebagai Wa'Turup. Konon ceritanya beliau sudah lahir pada Jaman Kerajaan Syarif Hidayatullah dan dipercayai oleh

masyarakat setempat adalah orang yang pertama kali menginjakan kakinya di Pulau Tidung.

Ice gel adalah media gel untuk proses penyimpanan bahan dalam suhu rendah. Ice gel berfungsi sebagai pengganti es batu dan dry ice yang dapat dipakai berulang-ulang dan dapat menjaga suhu dingin hingga 12 jam dalam wadah seperi box styrofoam. Kelebihan ice gel adalah gel tetap kering atau tidak terkondensasi ketika suhu dingin mulai berkurang(Mike P, Matthew M.;2015). Selain itu, ice gel aman digunakan, tidak beracun, ramah lingkungan, dan cocok digunakan untuk penyimpanan dingin komoditi pertanian seperti buah. Ice gel umumnya digunakan untuk penyimpanan obat-obatan, namun saat ini penggunaannya telah dimanfaatkan untuk penanganan pasca panen pada hortikultura terutama pada distribusi (Jaya 2013).

Ice gel memiliki karakteristik membeku pada titik suhu dingin, dan mencair pada suhu yang rendah. Apabila dilihat berdasarkan jenis material yang digunakan, ice gel terbagi menjadi dua jenis, yaitu ice gel yang hanya berfungsi sebagai elemen pendingin dan ice gel yang berfungsi ganda (elemen pendingin sekaligus elemen pemanas). Ice gel yang hanya berfungsi sebagai elemen pendingin biasanya berwarna biru, sedangkan yang berfungsi ganda berwarna putih, sedangkan berdasarkan jenis kemasannya, ice gel dibagi menjadi ice gel dan ice pack. Ice gel dikemas 
DOI: https://doi.org/10.21009/sarwahita.151.06

P-ISSN: 0216-7484

E-ISSN: 2597-8926

dengan plastik biasa, sedangkan ice pack dikemas dengan plastik yang kaku (Jaya 2013).

\section{METODE PELAKSANAAN}

Metode pelaksanaan kegiatan PkM ini dengan menggunakan workshop, yaitu memberikan pengetahuan keterampilan secara khusus, melalui Ceramah dan Praktek dilapangan. Metode Ceramah dipilih untuk menyampaikan konsep-konsep yang penting untuk dimengerti dan dikuasai oleh peserta workshop, yang dikombinasikan dengan gambar-gambar, animasi dan video dan materi yang relative banyak secara padat, cepat dan mudah.

Metode Demonstrasi juga digunakan untuk proses kerja yaitu tahaptahap pengembangan rumput laut menjadi ice gel, dengan pengolahan menggunakan beberapa bahan pendukung kimia. Peserta bisa langsung mempraktekan apa urutan pembuatan ice gel.

Tujuan workshop adalah memberikan program pendidikan tunggal yang di rancang untuk mengajarkan atau memperkenalkan kepada peserta keterampilan praktis, teknis, atau ide-ide yang dapat digunakan dalam pekerjaan mereka atau kehidupan sehari-hari mereka, dalam hal ini adalah para petani rumput laut yang diberikan pendidikan dan informasi pemanfaatkan rumput laut.Workshop ini dibuat untuk masyarakat pulau tidung yang mempunyai minat yang sama atau bekerja sebagai petani rumput laut. Walau dalam pelaksaan terdapat beberapa kendala :

a. Pekerjaan sebagai petani rumput laut hanya sebagai sampingan sebagai sumber mata pencaharian sehari-hari, tinggal beberapa penduduk saja yang bertahan sebagai petani rumput laut.

b. Pekerjaan sebagai petani rumput laut, Sering gagal panen karena limbah laut, dari penduduk dan minyak kapal yang tumpah.

c. Panasnya Matahari yang menyebabkan pertumbuhan rumput laut cepat tinggi daunnya.

d. Masih banyak petani yang mengalami kesulitan dalam pemasaran rumput laut, dan pemanfaatan rumput laut, sehingga lebih senang dibeli oleh tengkulak yang datang.

Target Luaran lainnya adalah jurnal tentang workshop pemanfaatan rumput laut untuk ice gel, buku pedoman tentang pemanfaat algae, serta memperolehnya HaKI.

\section{HASIL DAN PEMBAHASAN}

Kegiatan workshop ini dimulai dari perjalanan tim dari Jakarta, yang mulaI titik kumpul di dermaga marina ancol pada hari Rabu 24 Oktober 2018. Perjalanan menggunakan speed boad pada pukul 08.00 menuju pulau Tidung, dengan perjalanan lebih kurang 2 Jam. Di pulau Tidung tim PkM dijemput oleh tim Aju yang sudah lebih dulu berangkat 1 hari sebelumnya, menuju lokasi di SDN 01, disana peserta sudah sebagian hadir dengan didampingi Pejabat Kelurahan Bapak Muhammad Sani, Bidang Pemberdayaan Masyarakat. Kegiatan 
DOI: https://doi.org/10.21009/sarwahita.151.06

P-ISSN: 0216-7484

E-ISSN: 2597-8926

dilakukan di salah satu kelas di SDN 01 pulau Tidung dengan peserta sebanyak 20 orang sebagian besar ibu-ibu dan bapak-

bapak yang menjadi petani rumput laut, juga dihadiri sebagian guru-guru SDN 01 Pulau Tidung.

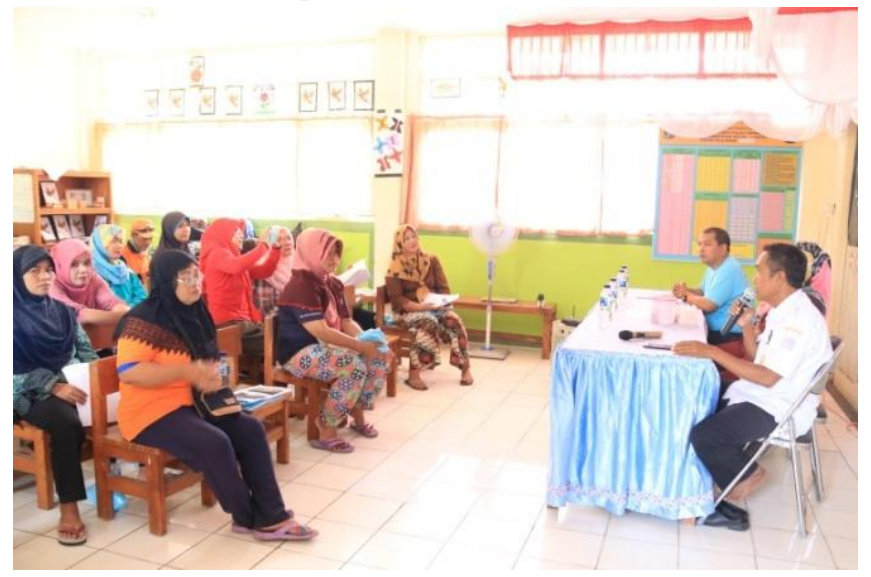

Gambar 1. Pembukaan kegiatan oleh pejabat setempat

Hasil Pada PkM tentang workshop pemanfaatan rumput laut menjadi Ice Gel ini, hasil yang diperoleh melalui angket dan pengamatan di lapangan, adapun hasil tersebut sebagai berikut :

a. Pengetahuan dari masyarakat atau petani tentang alga atau rumput laut terjadi peningkatan pengetahuannya.

b. Pengetahuan tentang pemanfaat rumput laut menjadi ice gel, menjadi

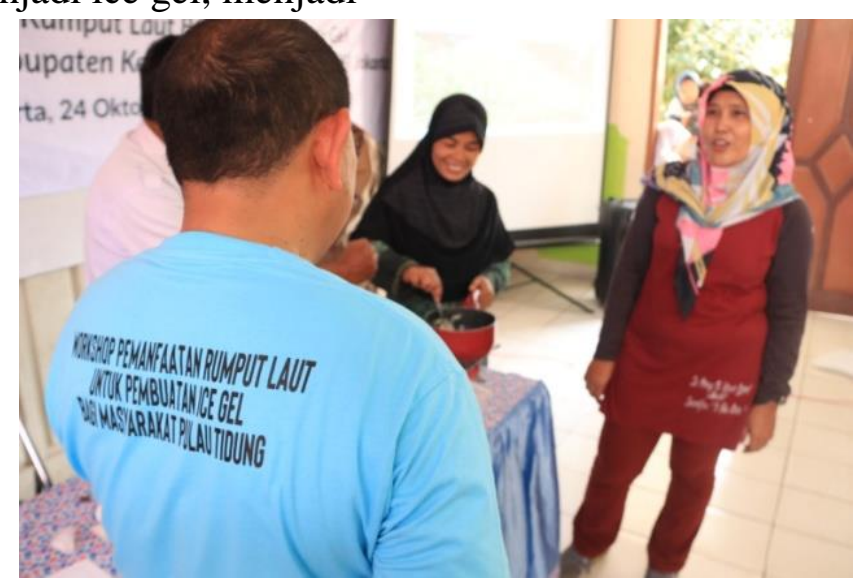

Gambar 2. Kegiatan workshop dengan partisipasi aktif dari masyarakat.

Sarwahita : Jurnal Pengabdian Kepada Masyarakat Vol. 15 No. 1 Tahun 2018 |60 
DOI: https://doi.org/10.21009/sarwahita.151.06

P-ISSN: 0216-7484

E-ISSN: 2597-8926

$\begin{array}{rrr}\text { Hasil } & \text { worshop } & \text { dengan } \\ \text { memperikan } & \text { pengetahuan } & \text { Cara }\end{array}$

Mengekstrasi Alga (saegassum

filipendula) menjadi Alginat, dimana

Prosedure ekstraksi alginate menurut

Rasyid (2003), Alga Coklat (Phaeophyta) sebagai sumber alginate oseana, Adalah sebagai berikut :

Rumput laut sargassumm

fillpendula kering seberat 5 gram direndam dalam larutan $\mathrm{HCl}$ 0,5\% selama 30 menit, dengan perbandingan 1:15 b/v (rumput laut:larutan $\mathrm{HCl}$ ) dengan tujuan untuk meningkatkan kadar alginate dan membebaskan garam-garam mineral. Selanjutnya dilakukan Perendaman berikutnya dilakukan menggunakan larutan $\mathrm{NaOH} 0,5 \%$ dengan perbandingan $1: 15 \quad \mathrm{~b} / \mathrm{v}$ (rumput laut: $\mathrm{NaOH} \quad 0,5 \%$ ) selama 30 menit, dengan tujuan untuk menghilangkan senyawa protein, Setelah perendaman rumput laut di ekstraksi dengan menginkubasi rumput laut tersebut dalam larutan $\mathrm{Na}_{2} \mathrm{CO}_{3} 2 \%$ pada suhu $60^{\circ} \mathrm{C}$ selama 60 menit. Selanjutnya, dilakukan penyaringan dengan kertas saring dan filtrate yang diperoleh ditambahkan larutan $\mathrm{NaOCl} \quad 10 \%$ sebanyak $2 \%$ dari jumlah filtrate yang dihasilkan, di aduk sampai warnanya berubah menjadi kuning.

Kemudian, filtrate yang diperoleh di atur $\mathrm{pH}$ nya menjadi 1-2 dengan menambahkan larutan $\mathrm{HCl} \quad 15 \%$ didiamkan 30 menit dan disaring menggunakan penyaring berukuran 40 mesh. Gel yang diperoleh kemudian dilarutkan dalam larutan $\mathrm{Na}_{2} \mathrm{CO}_{3} \quad 10 \%$ di 
DOI: https://doi.org/10.21009/sarwahita.151.06

P-ISSN: 0216-7484

E-ISSN: 2597-8926

pengering pada suhu $60-70^{\circ} \mathrm{C}$ selama 12 jam. (Ayuningtyas. 2011.)

Akhir kegiatan tim melakukan

evaluasi kepada peserta dan juga

juga sebagai petani rumput laut untuk mengeevaluasi hasil kegiatan tersebut. Selanjutnya memberikan sertifikat kepada wawancara singkat kepada peserta yang nara sumber dan juga kepada peserta.

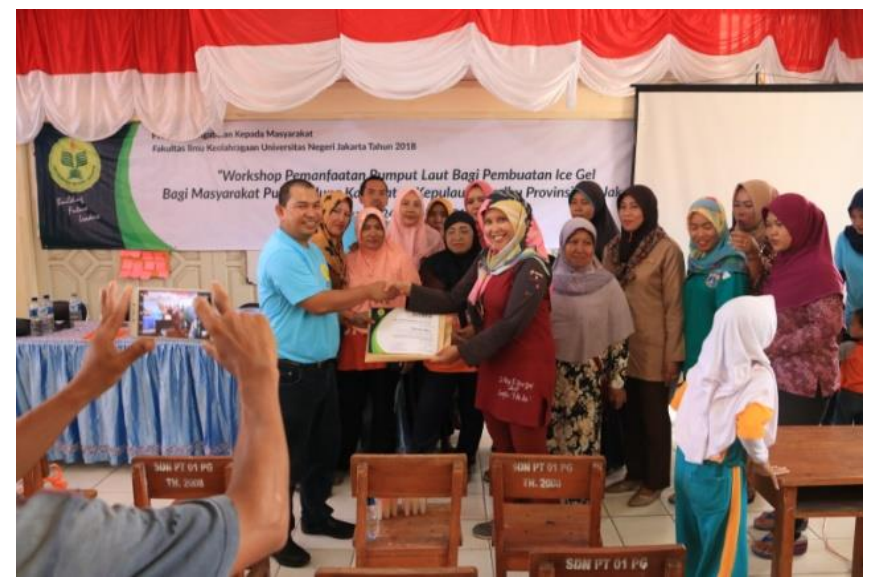

Gambar 3. Pemberian sertifikat kepada nara sumber dan peserta

\section{PENUTUP}

1. Kesimpulan

Kegiatan PkM ini dapat ditarik kesimpulan sebagai berikut :

a. Pengetahuan dari masyarakat atau petani tentang alga atau rumput laut meningkat sebelum dan sesudah sebesar rata-rata $30 \%$ menjadi $65 \%$.

b. Pengetahuan tentang pemanfaat rumput laut menjadi ice gel, sebelum dan sesudah workshop sebesar ratarata $20 \%$ menjadi $75 \%$.

c. Antusias peserta dalam kehadiran $100 \%$.

2. Saran

Beberapa saran yang dapat disampaikan PkM ini adalah :

a. Perlu sarana pendukung, dalam praktek kegiatan agar lebih aplikatif. b. Perlu waktu yang lebih lama lagi agar, proses pelaksanaan lebih tajam dan mendalam.

\section{DAFTAR PUSTAKA}

Afrianto, E., dan E. Liviawati. 1993, Budidaya Rumput Laut dan Cara Pengolahannya. Bhratara. Jakarta.

Anonymus. 2005, Prospect and Perspective of the Seaweed Industry for Building Capacities of Lokal Communities to Cope with Globalization (presentasi). Seaweed Industry Association of the Philipines. Manila.

Anggadiredja, J.T. 2007. Prospek Pasar Rumput Laut Indonesia di Pasar Global. Makalah disampaikan pada Lokakarya Implementasi Program Berkelanjutan Sulawesi Selatan Menuju Sentra Rumput 
DOI: https://doi.org/10.21009/sarwahita.151.06

P-ISSN: 0216-7484

E-ISSN: 2597-8926

Laut Dunia. Tanggal 7 Mei 2007. Makassar.

Anggadiredja, J.T.,A. Zatnika, H. Purwoto, dan S. Istini. 2006.

Rumput Laut; Pembudidayaan, Pengolahan dan Pemasaran

Komoditas Perikanan Potensial. Penebar Swadaya, Jakarta.

Angka , S.L. dan Maggy T. Suhartono. 2000. Bioteknologi Hasil Laut. Pusat Kajian Sumberdaya Pesisir dan Kelautan. Institut Pertanian Bogor. Bogor.

Atmadja, W. S., A. Kadi., Sulistijo, dan Rachmaniar. 1996. Pengenalan Jenis- Jenis Rumput Laut Indonesia. Puslitbang Oseanologi. Lembaga Ilmu Pengetahuan Indonesia. Jakarta.

Atmadja, W.S. dan Sulistija. 1988. Beberapa Aspek Vegetasi dan Habitat Tumbuhan Laut Bentik di Pulau-Pulau Seribu. Pusat Penelitian dan Pengembangan Oseanologi. Lembaga Ilmu Pengetahuan Indonesia. Jakarta.

Ayuningtyas. 2011. Ekstraksi agar. Laporan praktikum fikologi : halaman 4. Ketersediaan. http://www.scribd.com/doc/58871 960/Ekstraksi-Agar-Print-Smua.

(Tanggal 25 februari 2011). Chapman. V.J. 1974. Seaweeds and Their Uses 2rd edition. Methuein and Co.,Ltd. London. Chapman, V.J., and D.J. Chapman,1980. Seaweeds and
Their Uses 3th edition. Chapman and Hall, New York.

Dahuri, R. 2002. Pemanfaatan sumberdaya perairan di pesisir bagi pembangunan yang berkelanjutan melalui pengembangan industri budidaya. Prosiding Seminar Nasional Limnologi 2002. Hal : 1-22

Fatimah M.ST. 2012. Rumput Laut (euchema cottonii) Fakultas pertanian. UNHAS Makasar.

Johansyah L., and Dewi S., 2017, cooling Vests wool fibre for recovery activity', IJSEI (vol 6) ISSN (online) 2251-8843

Mike P, Matthew M. (2015). The effects of ice vest pre-cooling on skin blood flow at rest and during exercise in the heat. 15th International Conference on Environmental Ergonomics (ICEE XV) Portsmouth, UK. 28 June - 3 July 2015

Rasyid (2003), Alga Coklat (Phaeophyta) sebagai sumbel alginate oseana, Vol xxviii no 1:33-38. 